\title{
EFISIENSI INTERNAL SMK PROGRAM STUDI SEKRETARIS TAHUN PELAJARAN 1994/995 - 1996/1997 DI KABUPATEN KLATEN JAWA TENGAH
}

\author{
Oleh: \\ Winarso dan Dakir
}

\begin{abstract}
Abstrak
Tujuan penelitian untuk mengetahui efisiensi internal SMK Program Studi Sekretaris di Kabupaten Klaten Tahun Ajaran 1994/1995-1996/1997. Populasi sekaligus sebagai sampel penelitian yaitu 17 SMK yang terdiri dari 4 negeri dan 13 swasta. Uji validitas instrumen pada validitas tampak pertimbangan para ahli (expert iudgement).

Teknik analisis data dengan deskriptif dilanjutkan dengan cost-effectiveness analysis.

Hasil penelitian menunjukkan tingkat efisiensi internal sebagai berikut: Pertama: ditinjau dari indikator-indikator: 1. Masukan Pendidikan: a) rata-rata untuk pengeluaran gaji guru selama tiga bulan sebesar Rp. 5.379.470,00; b) rata-rata untuk pengeluaran fasilitas praktik selama tiga tahun sebesar Rp. 5.126.470,00; 2. Produk Pendidikan: a) rata-rata kenaikan kelas $99,99 \%$; b) rata-rata mengulang kelas $0.71 \%$ : c) rata-rata putus sekolah $0,94 \%$; d) rata-rata tingkat produksi pendidikan $99.99 \%$; 3 . Keluaran Pendidikan: a) rata-rata proporsi kelulusan 99,88\%; b) rata-rata nilai STTB Kejuruan 7,10; dan rata-rata NEM 6,41; 4. Ditinjau dari lama belajar peserta didik penyelenggaraan pendidikan hampir efisien, yaitu rata-rata selama 3,007 tahun, angka koefisien guru 0,87; Kedua: ditinjau dari perbandingan antara keluaran dengan masukan pendidikan: 1 . Secara keseluruhan bila dibandingkan antara keluaran dengan masukan, penyelenggaraan pendidikan SMK Kabupaten Klaten efisien secara internal, dengan besarnya indek efisiensi internal sebesar 1,0289: 2. Perbandingan antara proporsi kelulusan dengan masukan gaji guru efisien secara internal, dengan besarnya indek efisiensi 1,0287: 3. Perbandingan antara proporsi kelulusan dengan masukan biaya fasilitas praktik efisien secara internal dengan indek efisiensi 1,$0025 ; 4$. Perbandingan antara proporsi kelulusan dengan masukan gaji guru dan biaya fasilitas praktik efisien secara internal dengan besarnya indek efisiensi 1,$0642 ; 5$. Perbandingan antara nilai STTB Kejuruan dengan masukan gaji guru hampir efisien secara internal, indek efisiensi 0,$9990 ; 6$. Perbandingan antara nilai STTB Kejuruan dengan masukan biaya fasilitas praktik efisien secara internal dengan besarnya indek efisiensi 1,0749; 7. Perbandingan antara nilai STTB Kejuruan dengan masukan gaji guru dan biaya fasilitas praktik penyelenggaraan pendidikan ini efisien secara internal dengan indek efisiensi 1,$00372 ; 8$. Perbandingan antara NEM dengan masukan gaji guru menunjukkan penyelenggaraan pendidikan ini efisien secara internal, yaitu
\end{abstract}


dengan indek efisiensi 1,0136; Ketiga: Ditinjau dari biaya pendidikan: 1. Besarnya biaya kelulusan per lulusan berdasarkan gaji guru selama tiga tahun (Cycle Cost) rata-rata sebesar Rp. 4.503.870,00; 2. Besamya biaya kelulusan per lulusan berdasarkan gaji guru selama satu tahun dan satu bulan (unit cost) rata-rata sebesar Rp. 1.560.055,00 dan Rp. 130.004,00 dengan biaya paling minimal (least cost) adalah Rp. 881.600,00; 3. Besarnya Attrition Cost Index sebesar 9,0212 yang berarti penyelenggaraan pendidikan ini efisien secara internal.

Kata kunci: efisiensi internal, cost effectiveness analysis.

\section{Pendahuluan}

Pendidikan masa depan harus berfungsi sebagai bagian dari penyiapan sumber daya manusia (SDM) yang kuat. Menurut Boediono, (1997:56) fungsi pendidikan masa depan mencakup: peningkatan produktivitas kerja, peningkatan produsen teknologi untuk menerapkan dan menciptakan teknologi baru, peningkatan jumlah konsumen teknologi produk yang dapat mengonsumsi barang dan jasa yang mempunyai kandungan teknologi, dan peningkatan kemampuan komunikasi pendidik untuk meningkatkan produktivitas dan memasarkan hasil-hasil produksi.

Program pendidikan di sekolah menengah kejuruan, sebagai salah satu jalur pendidikan kejuruan dalam beberapa waktu ini telah banyak dikritik. Salah satu kritik yang dilontarkan adalah berhubungan dengan efisiensi pendidikan.

Menurut pendapat Mulyani (1991) sekolah kejuruan dipandang dari segi ekonomi juga tidak efisien karena tingkat penggunaan fasilitas pendidikan tinggi. Sementara itu, hasil yang diperolehnya masih tetap rendah. Menurut Windham (1987) pendidikan dikatakan mempunyai efisiensi internal yang tinggi apabila dalam penggunaan fasilitas dan peralatan sebagai masukan pendidikan adalah seminimal mungkin, tetapi dapat menghasilkan keuntungan pendidikan yang lebih besar (Windham, 1987). Oleh karena itu, dipandang perlu adanya peningkatan dan perluasan pen-didikan dan evaluasi mengenai efisiensi pendidikan. khususnya tentang efisiensi internal SMK Program Studi Sekretaris.

\section{Rumusan Masalah}

Dari latar belakang masalah, identifikasi masalah dan pembatasan masalah di atas, maka masalah-masalah dalam penelitian ini dirumuskan sebagai berikut: 
Seberapa besar tingkat Efisiensi Internal SMK Program Studi Sekretaris di Kabupaten Klaten ditinjau dari:

(1) masukan pendidikan

(2) produk pendidikan

(3) gabungan indikator satu dengan lainnya

(4) perbandingan dengan indikator-indikator keluaran terhadap masukan pendidikan

(5) besarnya biaya kelulusan peserta didik?

\section{Kajian Teoretik}

Pendidikan kejuruan merupakan subsistem dari sistem pendidikan. Terdapat banyak definisi yang diajukan oleh para ahli tentang pendidikan kejuruan, dan beberapa definisi tersebut berkembang seirama dengan persepsi dan harapan masyarakat tentang peran yang harus dimainkan. Dari definisi tersebut terdapat satu pengertian yang bersifat universal seperti yang dinyatakan oleh National Council for Research into Vocational Education (NCRVE, 1981) Amerika Serikat, yaitu bahwa pendidikan kejuruan merupakan subsistem pendidikan yang secara khusus membantu peserta didik dalam mempersiapkan diri memasuki lapangan kerja. Dari batasan yang diajukan oleh NCRVE tersebut dapat disimpulkan bahwa salah satu ciri pendidikan kejuruan dan yang sekaligus membedakannya dengan jenis pendidikan lain adalah orientasinya pada penyiapan peserta didik untuk memasuki lapangan kerja. Agak berbeda dengan yang dikemukakan oleh NCRVE, Finch, dan Crunkilton (1979) menyebut pendidikan kejuruan sebagai pendidikan yang mem-berikan bekal kepada peserta didik untuk dapat bekerja guna menopang kehidupannya.

Efisiensi, menurut Charles Linblon seperti dikutip oleh Dochak Latief (1975) adalah perbandingan antara nilai keluaran dan masukan atau perbandingan antara hasil kerja melalui mekanisme tertentu dengan tenaga (sebagai masukan) yang dipergunakan. The Liang Gie (1981) mengatakan bahwa efisiensi adalah suatu usaha mencapai prestasi sebesar-besamya dengan menggunakan sumber daya dan atau dana yang tersedia dalam tempo yang sesingkat-singkatnya.

Berdasarkan pengertian efisiensi di atas dapat disimpulkan bahwa efisiensi adalah sebagai daya guna, baik didasarkan atas tenaga, materi, pikiran, maupun waktu (The Liang Gie, 1981). Perbandingan dalam pengertian

\section{Winarso dan Dakir}


di atas dapat dilihat dari segi hasil (kuantitas dan atau kualitas) terhadap masukan atau usaha yang digunakan. Suatu pekerjaan disebut efisien apabila dapat menghasilkan sesuatu yang optimal dengan masukan minimal. Sebaliknya, suatu pekerjaan dikatakan tidak efisien (boros) apabila hasil yang diperoleh lebih kecil daripada usaha yang dilakukan.

Menurut Mulyani (1993), secara ekonomik konsep efisiensi sering diperten-tangkan dengan konsep yang lain seperti efektivitas, produktivitas, mutu, dan pemerataan pendidikan.

Efisiensi internal adalah tingkat efisiensi pada sistem internal pendidikan dalam mengalokasikan masukan pendidikan untuk menghasilkan keluaran yang tinggi (Boediono et al, 1992). Secara teknis efisiensi internal diartikan sebagai perbandingan antara keluaran dengan kombinasi masukan pendidikan (misalnya dari kombinasi biaya riil masukan). Sebaliknya, efisiensi eksternal adalah tingkat efisiensi pada sistem eksternal pendidikan mengalokasikan kombinasi masukan untuk menghasilkan outcomes yang tinggi. Oleh karena itu secara teknis efisiensi eksternal dapat dikatakan sebagai perbandingan antara outcomes dengan biaya riil dan kombinasi masukan.

Senada dengan itu World Bank (1990) mengatakan bahwa tingkat efisiensi internal pendidikan secara kuantitatif dapat ditunjukkan oleh besar kecilnya pemborosan pendidikan, misalnya angka putus sekolah dan mengulang kelas, sedangkan secara kualitatif akan ditunjukkan oleh tingkat perbandingan antara keluaran terhadap masukan pendidikan. Perbedaan antara efisiensi internal dengan eksternal dapat dilihat pada gambar berikut. 


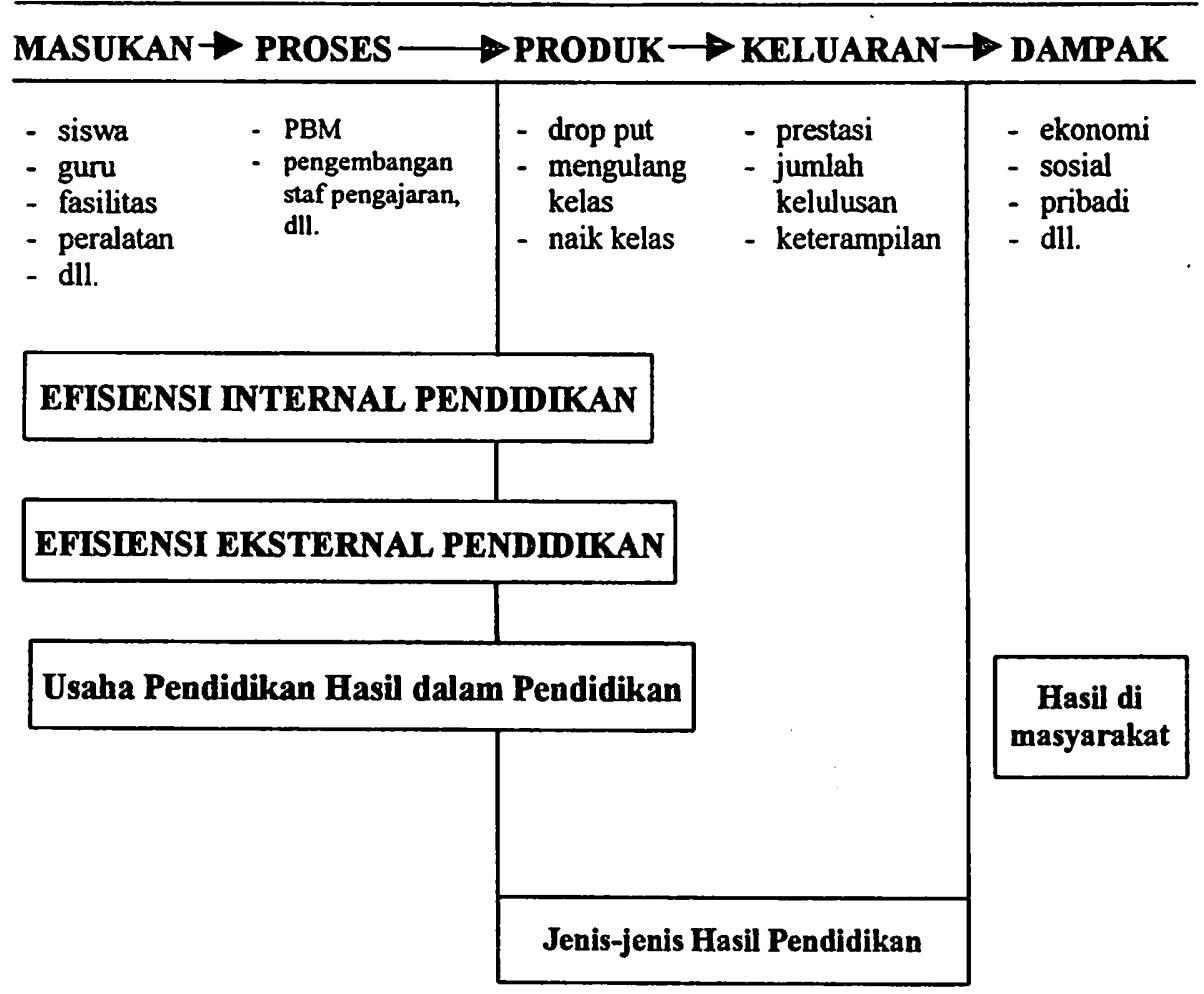

Gambar 1. Efisiensi dalam sistem pendidikan

(Sumber: Kaufman (1981) Joumal of Instructional Development, V4,9,19)

\section{Metode Pengumpulan Data dan Analisis Data}

Penelitian ini dilakukan terhadap dokumen sekolah, yang meliputi: data identitas sekolah, peserta didik, tenaga kependidikan, gaji guru, harga alat praktek, kelulusan, dan prestasi akademik mulai angkatan tahun 1994/1995 sampai dengan tahun 1996/1997. Dengan demikian, jenis datanya adalah bersifat sekunder. 
Rancangan evaluasi efisiensi internal dari sistem pendidikan yang digunakan adalah jenis Organizational Element Model (OEM) (Kaufman, et al., 1980; Kaufman dan Thomas, 1981). Untuk keperluan tersebut rancangan evaluasi ini disusun berdasarkan kepentingan estimasi.

Berdasarkan model evaluasi tersebut, sistem pendidikan di SMK dapat dibagi ke dalam unsur yang selanjutnya disebut sebagai model input-processproduct-output-outcomes atau model masukan-proses-produk-keluarandampak, yang akan digunakan sebagai dasar evaluasi. Sesuai dengan kepentingan evaluasi efisiensi internal pendidikan di SMK, diperlukan adanya modifikasi terhadap model tersebut yang selanjutnya dirancang menjadi model input-product-output atau masukan-produk-keluaran.

Populasi penelitian ini adalah SMK negeri dan swasta di Kabupaten Klaten Jawa Tengah dengan Program Studi Sekretaris untuk tahun ajaran 1994/1995 sampai dengan tahun 1996/1997.

Pengumpulan data dalam penelitian ini dilakukan dengan menggunakan metode wawan cara dan dokumentasi. Metode dokumentasi digunakan untuk meng-ungkapkan semua data yang telah terjadi pada tahun-tahun yang telah lalu, sedang-kan metode wawancara digunakan sebagai pelengkap data dari dokumentasi.

Untuk menjaring data penelitian, digunakan pedoman untuk pengisian data instrumen yang berupa daftar isian. Daftar isian ini merupakan adopsi dai kuesioner Balitbang Depdikbud yang telah dipergunakan untuk mengumpulkan data sekolah SMK dari tahun 1994/1995 - 1996/1997.

Cara untuk mengungkap efisiensi internal tersebut adalah dengan membandingkan antara indikator keluaran terhadap masukan pendidikan. Kemudian dilanjut-kan dengan menggunakan teknik analisis cost-effectiveness ienis attrition-cost, serta dengan analisis biaya minimal atau least-cost (Mulyani, 1993). Alasan penggunaan analisis biaya minimal atau kelulusan diperhitungkan berdasarkan atas lama belajar peserta didik yang bervariasi dari yang tepat tiga tahun ataupun yang lebih dari tiga tahun sehingga teknik analisis unitcost dan cycle-cost tidak dipergunakan.

Tidak dipergunakannya teknik analisis lainnya karena didasarkan pada beberapa pertimbangan. Pertimbangan tersebut adalah: (a) tidak digunakannya teknik analisis biaya per unit tambahan keluaran pendidikan, dalam penelitian ini karena datanya bersifat dokumentasi; (b) tidak dipergunakannya teknik analisis cost per unit of dipersion, karena dalam penelitian ini tidak 


\section{Efisiensi Internal SMK Program Studi Sekretaris Tahun Pelajaran 1994/1995-1996/1997 di Kabupaten Klaten Jawa Tengah}

mengungkap tingkat efisiensi yang didasarkan pemerataan pendidikan di berbagai daerah; (c) dan tidak diguna-kannya analisis cost-utility, karena dalam penelitian ini pengukuran keluaran pendidikan adalah secara agregat dari sekolah, bukan mengukur keluaran pendidikan yang sifatnya subjektif (per individu) peserta didik.

Langkah-langkah analisis deskriptif tersebut sebagai berikut: Pertama, untuk memper-mudah dalam analisa maka data dipilih atau dipisahkan untuk disesuaikan dengan kebutuhan formulasi tiap-tiap analisisnya. Kedua, dengan melakukan transformasi data. Maksudnya adalah dengan jalan menambah, mengurangi, mengalikan, dan atau membagi data yang akan dipergunakan. Ketiga, memaparkan hasil dari tiap-tiap penghitungan langkah sebelumnya untuk memberikan pengertian tentang tingkat efisiensi internal SMK. Maksudnya adalah untuk menjelaskan atau menginterpretasikan besarnya tingkat efisiensi internal SMK ditinjau dari indikator-indikator pendidikan.

Langkah analisis yang kedua didasarkan atas perbandingan antara keluaran dengan masukan pendidikan. Langkah analisis ini dilakukan sebagai berikut: Pertama, dengan melakukan standarisasi indikator-indikator masukan ataupun tingkat efisiensi internal dengan cara membandingkan antara indikator keluaran terhadap masukan, baik secara sendiri-sendiri maupun secara agresi sehingga didapatkan teknik cost-effectiveness dan Least-cost analysis. Kedua, menghitung tingkat efisiensi internal dengan cara membandingkan antara indikator, keluaran terhadap masukan, baik secara sendiri-sendiri maupun secara agresif, sehingga didapatkan teknik cost-effectiveness dan least-cost analysis. Ketiga, dengan memberikan makna terhadap hasil analisis tersebut termasuk di dalamnya adalah mendiskripsikan perbedaan efisiensi dalam penggunaan masukan yang berbeda.

\section{Hasil Penelitian}

Berdasarkan data yang diperoleh dapat dijelaskan bahwa rerata pengeluaran seluruh SMK Kabupaten Klaten Jurusan Sekretaris untuk menggaji guru selama tahun ajaran 1994/1995 sampai dengan 1996/1997 sebesar Rp. 5.379.470,00.

Hasil penelitian menunjukkan bahwa setiap SMK dalam kurun waktu tiga tahun biaya untuk mengadakan peralatan praktik rata-rata sebesar Rp. $5.126 .470,00$. Angka kenaikan kelas dari tahun 1994/1995 sampai dengan $1996 / 1997$ rata-rata sebesar $99,99 \%$. 
Angka mengulang kelas dari tahun 1994/1995 sampai dengan 1996/1997 rata-rata sebesar $0,71 \%$. Tingkat produksi pendidikan selama tiga tahun sebesar 99,99\%. Tingkat kelulusan SMK Kabupaten Klaten Jurusan Sekretaris tahun 1996/1997 rata-rata 99,88\%. Nilai STTB rata-rata adalah 7,10. Lama belajar peserta didik tahun 1996/1997 rata-rata sebesar 3,007 tahun dari standar lama belajar tiga tahun. Angka koefisien guru tahun 1996/1997 rata-rata adalah sebesar 0,87 .

\section{Efisiensi Internal SMK Ditinjau dari Perbandingan Indikator Keluarga terhadap Masukan dan Biaya Kelulusan}

Efisiensi internal SMK tahun 1996/1997 di Kabupaten Klaten Jurusan Sekretaris diperoleh tingkat efisiensi internal sebesar 1,0289. Tingkat efisiensi internal ditinjau dari perbandingan antara indikator proporsi kelulusan (sebagai hasil atau kelulusan pendidikan) terhadap gaji guru (sebagai biaya atau masukan pendidikan) di SMK Kabupaten Klaten Jurusan Sekretaris tahun 1996/1997 adalah sebesar 1,0287 (efisien).

Ditinjau dari perbandingan antara indikator proporsi kelulusan (sebagai hasil atau keluaran pendidikan) terhadap biaya peralatan praktik (sebagai biaya atau masukan pendidikan) sebesar 1,0025 (efisien).

Dari perbandingan antara indikator proporsi kelulusan (sebagai hasil atau keluaran pendidikan) terhadap biaya peralatan praktik dan gaji guru (sebagai biaya atau masukan pendidikan) sebesar 1,0642 (efisien).

Tingkat efisiensi internal ditinjau dari perbandingan antara indikator nilai STTB kejuruan atau prestasi kejuruan (sebagai hasil atau keluaran pendidikan) terhadap gaji guru (sebagai biaya atau masukan pendidikan) di SMK Kabupaten Klaten Jurusan Sekretaris sebesar 0,9990 (hampir efisien).

Efisiensi internal ditinjau dari perbandingan antara indikator nilai STTB kejuruan atau prestasi kejuruan (sebagai hasil atau keluaran pendidikan) terhadap biaya peralatan praktik (sebagai biaya atau masukan pendidikan) di SMK Kabupaten Klaten Jurusan Sekretaris sebesar 1,0749 (efisien).

Tingkat efisiensi internal ditinjau dari perbandingan antara indikator nilai STTB kejuruan atau prestasi kejuruan (sebagai hasil atau keluaran pendidikan) terhadap biaya gaji guru dan biaya peralatan praktik (sebagai biaya atau masukan pendidikan) di SMK Kabupaten Klaten Jurusan Sekretaris sebesar 1,00372 (efisien). 
Efisiensi internal ditinjau dari perbandingan antara indikator nilai NEM (sebagai hasil atau keluaran pendidikan) terhadap gaji guru (sebagai biaya atau masukan pendidikan) di SMK Kabupaten Klaten Jurusan Sekretaris adalah sebesar 1,0136 (efisien). Biaya per lulusan berdasarkan gaji guru selama tiga tahun atau selama menempuh studi di SMK rata-rata (Cycle cost) adalah $\mathbf{R p}$. 4.503.870,00. Dengan kata lain bahwa rata-rata biaya kelulusan per peserta didik sebesar Rp. 1.560.055,00/tahun atau Rp. 130.004,00/bulan (sebagai unit cost).

Attrition Cost Index adalah angka indeks biaya penyelenggaraan pendidikan yang merupakan ratio antara cycle cost terhadap unit cost dikalikan dengan lama belajar rata-rata peserta didik. Dalam penelitian ini hasilnya menunjukkan bahwa besarnya AC rata-rata di SMK Kabupaten Jurusan Sekretaris adalah 9,0212 (efisien secara internal, standarnya 9).

\section{Simpulan}

Berdasarkan hasil analisis data dan pembahasan dapat disimpulkan bahwa penyelenggaraan pendidikan SMK Program Studi Sekretaris di Kabupaten Klaten tahun ajaran 1994/1995 - 1996/1997 efisien secara internal.

\section{Daftar Pustaka}

Boediono, McMahon, Walter W., and Don Adams. (1992). Education, economic and social development. Jakarta: Balitbang - Depdikbud.

(1992). Studi mutu dan efisiensi pendidikan menengah. Jakarta: Balitbang - Depdikbud.

, (1992). Internal efficiency in education. Jakarta:'Depdikbud.

Coombs, Philip J. dan Hallak (1987), Cost analysis in education. Baltimore 'dan London: The John Hopkins University Press.

Depdikbud (1990). Program pengembangan pendidikan menengah kejuruan dalam Pelita V. Jakarta: Dirjen Dikdasmen - Dikmenjur.

(1998). Indikator Pendidikan. Jakarta: Balitbang - Depdikbud. 
Jiyono (1980). Cara mnegukur mutu pendidikan, analisis pendidikan, tahun I Nomor 2, hal 81, Jakarta - Depdikbud.

Kauffman, Roger et al. (1981). Relating Needs Assesment, Program development, implementation, and evaluation. Journal of introductional development. 4 (4), 0. 19. Tallahassee: The Florida State University.

Nurhadi, Mulyani A. (1989). Cost-benefit analysis. (Naskah Penataran Studi Kasus dan Penelusuran). Yogyakarta: FIP IKIP Yogyakarta.

, (t.th). Analisis ekonomi pendidikan. Yogyakarta: FPI IKIP Yogyakarta.

, (1990). Studi efisiensi eksternal lulusan SMTA vokasional di kawasan pengembangan industri VII Gresik Jawa Timur. (Penelitian). Yogyakarta: FPI IKIP Yogyakarta.

(1991). Evaluasi program pendidikan. (Makalah) Yogyakarta: PPS IKIP Yogyakarta.

(1993). Efisiensi pendidikan. (Karya Ilmiah). Yogyakarta: FIP IKIP Yogyakarta.

The Liang Gie (1981). Efisiensi kerja bagi pembangunan negara. Yogyakarta: Gajah Mada University Press.

Windham, Douglas M. (1987). Indicators of educational effectiveness and efficiency. New York: State University of New York at Albany. 